\title{
POLA ASUH IBU TUNGGAL DALAM MENGEMBANGKAN KECERDASAN SOSIAL ANAK USIA DINI (Studi Deskriptif pada Anak Usia 4 - 6 Tahun)
}

\author{
Rizka Fadliah Nur
}

\begin{abstract}
The purpose of this study was to determine the role of mothers as single parents in developing their children's intelligence at the age of 4-6 years. This study uses a descriptive quantitative approach with a single variable, namely social intelligence. Social intelligence consists of aspects of social sensitivity, social insight, and social communication. This aspect of social intelligence must be possessed by early childhood. Social intelligence includes empathy, prosocial, self-awareness, understanding of social situations and social ethics, problem solving skills, effective communication, effective listening and being able to lead groups. These skills can be taught to children starting from an early age by their parents, mothers who act as single parents have their own ways to help their children's development because social intelligence in early childhood is not naturally possessed by children, but must be grown and developed. by parents by developing the social and emotional aspects of early childhood. That is why we need various methods that can be used to develop it. One method that parents can use in developing social and emotional aspects in early childhood is through example. Exemplary activities that can be done to develop emotional social intelligence in early childhood.
\end{abstract}

\section{Keywords: Single Mother Parenting, Social Intelligence, Early Childhood.}

\section{PENDAHULUAN}

Keluarga adalah kelompok terkecil dari masyarakat yang terdiri dari suami atau ayah (berperan sebagai kepala keluarga) dan beberapa orang yang hidup bersama di bawah satu atap dalam kondisi yang saling membutuhkan/ ketergantungan, keluarga yang ideal biasanya terdiri dari ayah, ibu dan anak. Dalam sebuah keluarga ada keluarga yang lengkap dan keluarga yang bercerai, keluarga lengkap adalah keluarga yang terdiri dari anak tinggal dalam suatu kebersamaan dengan kedua orang tua biologisnya sedangkan keluarga yang bercerai adalah keluarga yang tidak memiliki hubungan yang harmonis dan 
mengarah pada perceraian anak terhadap orang tua, oleh karena itu anak tinggal dengan salah satu orang tua biologisnya.

Keluarga yang lengkap atau keluarga utuh dapat mengoptimalkan potensi anak, sebab orangtua dapat bekerjasama dalam mendidik dan mengasuh anak. Hal ini dikarenakan orangtua merupakan objek pertama pembelajaran anak. Beberapa kasus seorang anak hanya di asuh oleh salah satu orangtua saja yang biasa disebut keluarga dengan orangtua tunggal, hal yang menyebabkan keluarga tidak ideal tersebut antara lain; 1). Perceraian; 2). Kematian; 3). Orangtua tidak menikah; 4). Orang tua yang bekerja jauh. ${ }^{1}$ Fenomena sosial kini sangat memperihatinkan di Indonesia, banyak sekali keluarga yang tidak lengkap akibat perceraian sehingga banyak anak usia dini yang hanya diasuh oleh salah satu orang tuanya saja seperti di asuh oleh ibu kandungnya saja.

Anak merupakan generasi penerus bangsa dan juga harapan bagi setiap orang tua. Anak merupakan bagian dari masyarakat yang mengemban tanggung jawab pembangunan suatu bangsa di masa yang akan datang. Baik atau buruknya suatu bangsa di masa depan bergantung pada pengembangan kualitas anak-anak saat ini. Hal ini menunjukkan bahwa anak-anak perlu dipersiapkan agar mampu menjadi sumber daya manusia suatu bangsa yang berkualitas. Mempersiapkan masa depan anak dimulai pada usia keemasan (4-6 tahun). Masa usia dini merupakan periode pertumbuhan dan perkembangan yang sangat pesat, baik aspek fisik, emosi, sosial, bahasa, maupun kogniitif. Pada usia prasekolah, otak anak mengalami pertumbuhan sel yang pesat. Usia 5 tahun otak anak mencapai $50 \%$ dari otak orang dewasa, dan tumbuh hingga $80 \%$ pada usia 8 tahun $^{2}$. Pada usia golden age ini anak butuh bimbingan dan perhatian dari kedua orang tuanya dalam mengembangkan kecerdasannya.

Perkembangan kecerdasan anak usia dini tidak terlepas dari peran orang tua (ibu) sebagai orang tua tunggal, Peran ibu sangatlah besar. Diantara peran yang sangat penting tersebut dalam hal pendidikan dan penanaman karakter ilmiah pada anak. Peran ibu saat menjadi orang tua tunggal adalah suatu perubahan sikap

\footnotetext{
${ }^{1}$ J. Brooks, The Process of Parenting. (Yogyakarta: Pustaka Pelajar, 2011), 27.

${ }^{2}$ Elizabeth B. Hurlock, Perkembangan Anak. (Jakarta: Erlangga, 2010).
} 
yang mendasarkan dengan keadaan yang dialami. Seorang ibu akan memberikan kasih sayang kepada anaknya secara ikhlas dan tanpa pamrih. Ia memberi cinta pada anak-anaknya tulus dan sungguh-sungguh bersedia mengutamakan kepentingan anak-anaknya diatas kepentingan pribadinya. Perkembangan anak usia dini yang sangat pesat membutuhkan rangsangan dari lingkungan sekitar agar dapat berkembang secara optimal. Peran ibu sebagai orang tunggal dapat menyebabkan perubahan sikap yang mendasar dengan keadaan yang dialami anak. Dengan sendirinya pola hidup mandiri anak selalu melekat dan menjadikan ibu sebagai seorang yang mampu bertahan hidup. Dengan keadaan yang tidak seimbang yaitu dengan mempunyai dua peran. Oleh sebab itu peran ibu sebagai orang tua tunggal lebih berat karena mengemban dua tugas, yaitu berperan mengemban tugas ayah sebagai pembimbing, kepala rumah tangga, pencari nafkah, tauladan untuk anak, dan tugas seorang ibu yaitu pembimbing, pendidik dll dalam menyikapi perubahan-perubahan dalam pribadi anak ${ }^{3}$. Pendampingan orang tua dalam proses belajar anak dalam memberikan rangsangan belajar anak dengan memberikan fasilitas belajar serta pengawasan dalam bersosialisasi dengan teman dan lingkungan sosialnya ${ }^{4}$. Pemberian rangsang perkembangan pada anak usia dini dapat dilakukan melalui pendidikan. Oleh karena itu, negara telah mengatur pendidikan bagi anak usia dini melalui Undangundang nomor 20 tahun 2003 tentang sistem pendidikan nasional. Menurut undang-undang tersebut, pendidikan anak usia dini merupakan tindakan pemberian rangsangan pendidikan terhadap perkembangan dan pertumbuhan jasmani dan rohani anak usia dini. ${ }^{5}$

Pola asuh yang di berikan oleh ibu sebagai orang tua tunggal pada anak usia dini dibutuhkan untuk penanaman emosi yang baik Pola asuh ibu yang tepat akan membentuk anak usia dini yang memiliki kecerdasan sosial yang positif. Kemampuan mengolah emosi dengan baik pada diri sendiri dan orang lain, menggunakan perasaan-perasaan itu untuk memandu pikiran dan tindakan dengan

${ }^{3}$ M. Save Dagun, Psikologi Keluarga, (Jakarta: Rineka Cipta, 2011), 97.

${ }^{4}$ Ardiansyah, A., \& Arda,A. Peran Orang Tua dalam Proses Belajar Anak di Masa Pandemi Covid-19 dalam Menumbuhkan Sikap Ilmiah (Musawa, Journal For Gender Studies, Vol. 12, No. 1, 2020), 140-164.

${ }^{5}$ Pebriana, P., H. Analisis Penggunaan Gadget terhadap Kemampuan Interaksi Sosial Anak Usia Dini. Journal Obsesi (Journal of Early Chilhood Education, Vol. 1, No. 1, 2017), 1-11. 
menggunakan kecerdasan sosial. Gardner menjelaskan bahwa kecerdasan terdiri dari kecerdasan antar pribadi yaitu kemampuan memahami orang lain yang memotivasi mereka dan cara mereka bekerja. Sedangkan kecerdasan intra pribadi adalah kemampuan yang korelatif, tetapi terarah ke dalam diri. Kemampuan tersebut adalah kemampuan membentuk suatu model diri sendiri yang teliti dan mengacu pola asuh dan linghkungan belajar anak. ${ }^{6}$

Kecerdasan sosial pada anak diharapkan dapat membentuk kepekaan sosial yang tinggi. dalam kehidupan bermasyarakat sebagai "aktor sosial" (social actor). Salah satu kemampuan yang dituntut untuk menjadi keputusan seorang social actor yang baik adalah mengambil keputusan secara nalar atau well informed and reasoned decision making ${ }^{7}$. Anak yang memiliki kecerdasan sosial mampu berinteraksi dengan orang lain dengan selalu memperkirakan perasaan, temperamen, suasana hati, maksud dan keinginan teman interaksinya, kemudian memberikan respon yang layak. Orang dengan potensi kecerdasan sosial memiliki kemampuan sedemikian sehingga terlihat amat mudah bergaul, banyak teman dan disenangi oeh orang lain. Di dalam interaksi sosial anak menunjukkan kehangatan, rasa persahabatan yang tulus, empati serta dapat juga menyelesaikan berbagai persoalan yang berhubungan dengan perselisihan orang lain. Kecerdasan ini sangat penting, karena pada dasarnya kita tidak dapat hidup sendiri. Sehingga anak yang memiliki kecerdasan sosial akan mudah menyesuaikan diri, menjadi orang dewasa yang sadar secara sosial dan berhasil dalam pekerjaan.

Demi memenuhi kecerdasan sosial pada anak, ibu berperan besar sebagai pendidikan pertama yang akan dialami anak, pendidikan dan pengajaran yang diberikan ibu dapat berpengaruh dalam kehidupan sosial anak untuk tumbuh dan berkembang sesuai dengan tingkat pencapaian perkembangan anak seperti, moral agama, sosial dan emosi. Anak yang di asuh dan di stimulasi dengan baik akan optimal perkembangan potensi anak sebagai persiapan untuk hidup dan dapat menyesuaikan dan berinteraksi dengan lingkungannya. Perkembangan anak usia

${ }^{6}$ Daniel Goleman, Working With Emotional Intelligence (terjemahan), (Jakarta: PT. Gramedia Pustaka Utama, 2002), 52.

${ }^{7}$ Stahl, R.J., Cooperative Learning in Social Studies, Handbook for Teachers, (USA: Kane Publishing Service, Inc, 1994). 
dini diharapkan sudah mencapai perkembangan secara optimal dalam berbagai aspek seperti perkembangan kognitif, moral, sosial dan emosi sehingga anak memiliki kesiapan sekolah yang baik. Peraturan Menteri Pendidikan Nasional No.137 Tahun 2014 menyatakan bahwa perkembangan sosial anak usia 4-5 Tahun dikatakan berkembang sesuai harapan jika anak mampu memahami peraturan dan disiplin; menunjukan sikap mandiri dalam memilih kegiatan; mau berbagi, menolong, dan membantu teman; menunjukan antusiasme dalam melakukan permainan kompetitif secara positif dan memiliki rasa empati dengan teman. Perlakuan orang tua terhadap seorang anak diwaktu kecil akan mempengaruhi tahap awal perkembangan mereka dan paling rentan terhadap pengaruh internal dan eksternal terhadap sosial-emosional. ${ }^{8}$

Pentingnya perkembangan kecerdasan sosial anak usia dini bergantung pada peran dan didikan orang tuanya. Pada anak-anak yang di asuh oleh orang tua tunggal ( ibu saja) tugas dan tanggung jawab ibu sebagai orang tua tunggal sangat berat sehingga kebutuhan pendampingan dan didikan pada anak menjadi berkurang karena duo peran yang harus dijalankan oleh ibu sebagai kepala keluarga untuk mencari dan mencukupi nafka keluarga juga sebagai peran ibu sebagai pendidikan pertama anak usia dini menjadi tidak maksimal. Permasalahan yang ditimbulkan bila kecerdasan sosial anak belum matang mengakibatkan sikap temperamen anak tinggi serta kesetabilan emosi anak menjadi rendah. Hasil penelitian Baer et al menyatakan bahwa anak yang memeiliki sikap temperamental emosional cenderung memiliki kompotensi sosial yang rendah ${ }^{9}$.

Kondisi di atas menunjukkan bahwa pengasuhan berpengaruh pada perkembangan kecerdasan sosial anak. Setiap keluarga tentu memiliki pola asuh yang berbeda-beda. Keluarga dengan ayah dan ibu yang lengkap tentu akan menghasilkan pola asuh yang berbeda dengan pola asuh yang diterapkan oleh

\footnotetext{
${ }^{8}$ Peraturan Menteri Pendidikan Nasional No. 137 tahun 2014. Tentang standar Nasional Anak Usia Dini. Jakarta, 2014.

${ }^{9}$ Robbiyah, Dian E, Ramadhan W. Pengaruh Pola Asuh Ibu terhadap Kecerdasan Sosial Anak Usia Dini di TK Kenanga Kabupaten Bandung Barat. (Jurnal Obsesi: Jurnal Pendidikan Anak Usia Dini, Vo. 2 No. 1. 2018), 76-84.
} 
keluarga dengan ibu tunggal. Dengan demikian, perbedaan pola asuh juga akan menghasilkan perkembangan kecerdasan sosial anak yang berbeda pula.

Berdasarkan latar belakang tersebut, penulis mengangkat penelitian tentang bagaimana pola pengasuhan ibu tunggal dalam mengembangkan kecerdasan sosial anak usia 4-6 tahun di dengan judul "Pola Asuh Ibu Tunggal Dalam Mengembangkan Kecerdasan Sosial Anak Usia Dini” (Studi Deskriptif Pada Anak Usia 4 - 6 Tahun).

\section{METODE}

Tujuan dari penelitian ini adalah untuk untuk mengetahui peranan ibu sebagai orang tua tunggal dalam mengembangkan kecerdasan anaknya di usia 4-6 tahun. Penelitian ini menggunakan pendekatan kuantitatif deskriptif dengan variabel tunggal yaitu kecerdasan Sosial. Subyek penelitian yang diambil merupakan anak-anak usia dini dan para ibu anak-anak tersebut Dalam melakukan penelitian ini, peneliti menggunakan metode penelitian kualitatif. Penelitian kualitatif adalah metode penelitian yang berlandaskan pada filsafat postpositivisme. Filsafat postpositivisme digunakan untuk meneliti pada kondisi obyek yang alamiah, (sebagai lawannya adalah eksperimen) dimana peneliti adalah sebagai instrumen kunci. Ukuran sampel didasarkan pada pencapaian kedalaman dan kekayaan deskripsi, bukan ukuran sampel.Menurut Guetterman $(2015)^{10}$, ukuran sampel bukan masalah opini representative dan pandangan, tetapi lebih merupakan masalah kekayaan informasi. Dalam penelitian ini, responden sebanyak. Subyek penelitian adalah Ibu senagai orang tua tunggal dan anaknya yang berusia 4-6 tahun yang terdiri atas 5 pasang. Teknik pengumpulan data yang digunakan adalah wawancara semi-terstruktu sebagai data primer, sedangkan data sekunder dikumpulkan dari data yang dipublikasikan seperti artikel jurnal-jurnal dan buku. data dianalisis dengan menggunakan tematik, yaitu teknik analisis yang menekankan pada penyusunan koding dengan mengacu pada pertanyaan penelitian yang telah ditetapkan, sehingga tema-tema yang tersusun sesuai dengan

\footnotetext{
${ }^{10}$ Agus Purwanto, dkk. Studi Eksploratif Dampak Pandemi COVID-19 Terhadap Proses Pembelajaran Online di Sekolah Dasar, (Journal of Education, Phychology and Counseling, Vol. 2 No. 1, 2020), 1-12.
} 
pertanyaan penelitian tersebut dan menjadi acuan dalam memaparkan fenomena yang terjadi. ${ }^{11}$

\section{HASIL DAN PEMBAHASAN}

\section{Pola Asuh Orang Tua}

\section{Pengertian Orang Tua}

Orang tua adalah orang dewasa pertama yang memikul tanggung jawab pendidikan, sebab secara alami anak pada masa-masa awal kehidupannya berada di tengah-tengah ibu dan ayahnya dan dari merekalah anak mulai mengenal pendidikan. $^{12}$

Menurut Imam Bernadib orang tua adalah pendidik utama. Karena sebagian besar waktu anak-anaknya banyak dihabiskan dengan orang tuanya, olehnya itu orang tua harus menumbuhkan kesadaran yang didasari rasa cinta dan kasih sayang yang mendalam mengasuh atau mendidik anaknya dengan penuh tanggung jawab dan kesabaran. ${ }^{13}$

Dengan demikian jelaslah bahwa orang tua memiliki kedudukan dan tanggung jawab yang sangat besar terhadap anaknya, tanggung jawab orang tua berupa memberikan nafkah, mendidik, mengasuh, serta memelihara anaknya untuk mempersiapkan dan mewujudkan kebahagiaan anak hidup di masa depan.

\section{Peran Orang Tua dalam Pendidikan Anak.}

Peran Orang tua dalam pendidikan anak sangat menentukan keberhasilan anak, adapun peran orang tua adalah sebagai berikut:

a. Sebagai Pendidik.

Orangtua berperan sebagai pendidik sebab dalam pekerjaannya tidak hannya mengajar, tetapi juga melatih ketrampilan anak, terutama melatih sikap mental anak ${ }^{14}$ Maka dalam hal ini, orang tua tidak bisa melimpahkan tanggung

\footnotetext{
${ }^{11}$ Heriyanto, H. (2018). Thematic Analysis sebagai Metode Menganalisa Data untuk Penelitian Kualitatif. Anuva. https://doi.org/10.14710/anuva.2.3. 317-324.

${ }^{12}$ Hery Noer Aly, Ilmu Pendidikan Islam, (Jakarta : PT. Logos Wacana Ilmu, 1999), 87.

13 Imam Bernadib, Pengantar Ilmu Pendidikan Sistematis, (Yogyakarta: Fakultas Ilmu Pendidikan, 1987), 61.

${ }^{14}$ Sardiman, Interaksi dan Motivasi Belajar Mengajar, (Jakarta: Raja Grafindo Persada, 1996), 72.
} 
jawab ini sepenuhnya kepada guru disekolah, harus ada kerja sama yang bersinergi antara orang tua siswa dengan pihak sekolah dalam menumbuhkan dan mensukseskan pendidikan anak.

b. Sebagai Pelindung.

Selain berperan sebagai pendidik, anak juga membutuhkan sosok pelindung. Orang tua adalah sosok pelindung yang menurut anak yang paling aman. Berbagai macam perlindungan yang dapat di peroleh anak dari orang tuanya seperti perlindungan yang bersifat Tut Wuri Handayani yakni memberikan perlindungan berupa bimbingan secara sadar terhadap anak sesuai minat, bakat, karakter dan kemampuan IQ anak. Selain itu orang tua juga memberi perlindungan eksternal yang berupa gangguan seperti: narkoba, miras, dekadensi moral, dan pergaulan bebas.

Dalam islam juga menjelaskan tugas dan fungsi orang tua sebagai pelindung anggota keluarganya, orang tua di tuntut memberikan jaminan material bagi kelangsungan hidup keluarganya. Hal ini dijelaskan dalam firman Allah SWT dalam surah Al-Thalaq ayat 6, yang artinya,

"Tempatkanlah mereka dimana saja kamu bertempat tinggal dan jangalah kamu memberi mudharat kepada mereka untuk menyempitkan atas mereka”.

Jelas dari ayat diatas orang tua mempunyai tugas dan tanggung jawab memberikan rasa aman dan nyaman dalam menumbuh kembangkan kepribadian anak yang lebih baik. ${ }^{15}$

c. Sebagai Motivator

Sebagai motivator, peran orang tua memberikan motivasi kepada anak dengan cara memberi penghargaan terhadap prestasi belajar anak dengan memberi hadiah maupun kata-kata pujian. Serta memberikan bantuan kepada anak dalam menghadapi kesulitan belajarnya dengan pemberian penjelasan pada bagian yang sulit dimengerti oleh anak. ${ }^{16}$

\footnotetext{
${ }^{15}$ Syafi'ah, Peran Orang Tua dan Keluarga, (Jurnal Sosial Budaya Vol.9 No. 1, 2012), 109

${ }^{16}$ Hening Hangesty Anurraga, Peran Orangtua dalam Meningkatkan Motivasi Belajar Peserta Didik Usia 6-12 Tahun, Fakultas Ilmu Pendidikan: Universitas Negeri Surabaya. 1-8.
} 
d. Sebagai Fasilitator.

Sebagai fasilitator dengan menyediakan sarana alat belajar seperti tempat belajar, buku-buku pelajaran dan alat-alat tulis dan memberikan fasilitas untuk mengembangkan bakat dan minat anak. Orang tua mempunyai andil yang besar dalam menumbuhkan motivasi ekstrinsik karena dengan adanya motivasi ekstrinsik dalam diri anak, sehingga keadaan jiwa dan psikologis anak yang labil dapat dikendalikan ${ }^{17}$.

e. Sebagai Pembimbing.

Peran orang tua sebagai pembimbing perlu meluangkan waktunya mendampingi anak-anakanya dalam proses belajar. Dalam islam juga menegaskan peran orang tua dalam membimbing proses belajar anaknya, hal itu dapat dilihat pada Hadist Rasulullah SAW yang artinya: "Setiap anak yang dilahirkan telah membawah fitrah sehingga fasih lidahnya, maka orang tuanyalah yang menjadikan anak tersebut yahudi, nasrani atau majusi "18

\section{Pengertian Ibu Orang Tua Tunggal}

Orang tua tunggal merupakan orang tua tunggal yang masih memiliki anak yang tinggal satu rumah dengannya atau dapat juga diartikan bahwa orang tua tunggal merupakan orang tua yang mengasuh dan membesarkan anaknya tanpa ada kehadiran pasangan (suami/istri) dalam keluarganya yang biasa dinamakan keluarga single parent. ${ }^{19}$

Santrock (2010) membagi keluarga single parent menjadi dua jenis, yaitu single father dan single mother. Single father merupakan keluarga dimana seorang ayah bertindak sebagai kepala keluarga sekaligus berperan sebagai ibu yang bertugas mengurus rumah tangga. Single mother merupakan keluarga yang dipimpin oleh seorang ibu yang bertindak sebagai kepala keluarga sekaligus mengurus rumah tangga. ${ }^{20}$ Ibu tunggal (Single mother) merupakan wujud akibat pembubaran ikatan pernikahan antara suami dan istri melalui cara perceraian yang

\footnotetext{
${ }^{17}$ Ibid, 1-8.

${ }^{18}$ Moh. Rifai. Peranan Orang Tua sebagai Wali, Pembimbing, dan Pendidik pada Perkembangan Anak dalam Perspektif Pendidikan Agama Islam (Jurnal Pendidikan Dasar dan Pembelajaran Vol. 1 No. 1, 2011), 51-63.

${ }^{19}$ Melia Dewi, Pola Pengasuhan Anak, (Bandung: PT. Remaja Rosdakarya, 2012), 58-59.

${ }^{20}$ John W. Santrock, Child Development. New York: McGraw-Hill, 2010.
} 
sah atau kematian. Selain itu, ibu tunggal juga termasuk wanita yang mngadopsi anak angkat.

Berdasarkan pengertian diatas di simpulkan bahwa ibu sebagai orang tua tunggal adalah seorang wanita yang tidak memiliki pasangan (suami) yang disebabkan oleh beberapa faktor seperti perceraian, di tinggal mati, pekerjaan pasangan yang berjarak sangat jauh yang membesarkan serta mengasuh anaknya tanpa kehadiran dan tanggung jawab dari pasangannya.

\section{Pola Asuh Ibu Tunggal.}

Pola asuh merupakan suatu cara terbaik yang dapat ditempuh orangtua dalam mendidik anak-anaknya sebagai tanggung jawab kepada anak-anaknya ${ }^{21}$. Pola asuh juga diartikan sebagai suatu proses yang ditujukan untuk meningkatkan serta mendukung perkembangan fisik, emosional, sosial, serta intelektual seorang anak sejak bayi hingga dewasa. Itulah mengapa orang tua mempunyai tanggung jawab besar dalam memberikan asuhan yang tepat untuk anak. Hasil penelitian terhadap perekmbangan anak yang tidak mendapat asuhan dan perhatian ayah menyimpulkan, perkembangan anak menjadi pincang. Kelompok anak yang kurang mendapat perhatian ayahnya cenderung memiliki kemampuan akademis menurun, aktivitas sosial terhambat dan interaksi sosial terbatas.

Bentuk pola asuh orang tua menurut Baumrind yang dapat dilakukan oleh orang tua dalam mengasuh anaknya yaitu ${ }^{22}$ :

a. Pola pengasuhan ototarian

Pola pengasuhan ini merupakan pola pengasuhan dimana orang tua membatasi dan menghukum anak serta memaksa anak untuk mengikuti aturan yang dibuat orangtua. Batasan-batasan dan aturan yang diterapkan orang tua sangat tegas bahkan perdebatan secara verbal sangat sedikit. Akibat yang sering ditimbulkan dari pengasuhan ini adalah anak kurang kompeten dalam bidang sosial. Dampak yang ditimbulkan dari pola asuh ini pada anak anatara lain sebagai berikut:

\footnotetext{
${ }^{21}$ Manshur, A. Pendidikan Anak Usia Dini, (Bandung: Pustaka Pelajar, 2005).

${ }^{22}$ John W. Santrock, Child Development. New York: McGraw-Hill, 2010.
} 
1) Memiliki keterampilan sosial yang baik

2) Terampil dalam menyelesaikan masalah.

3) Mudah bekerjasama dengan orang lain

4) Lebih percaya diri.

5) Tampak lebih kreatif.

b. Pola pengasuhan otoritatif.

Pola pengasuhan otoritatif merupakan pola pengasuhan yang menerapkan batas dan kendali namun orang tua memberikan motivasi kepada anak baik secara sikap maupun verbal. Pengasuhan ini menghasilkan anak yang kompeten secara sosial. Dampak negatif dari pola asuh otoritatif ini akan membawah pengaruh terhadap sifat-sifat anak, antara lain:

1) Tidak memiliki kekuatan untuk memilih

2) Tidak bisa mengambil keputusan sendiri

3) Takut salah

4) Tidak mempunyai kekuatan untuk mengatakan tidak

5) Takut mengemukakan pendapat

6) Kurang memiliki motivasi dalam diri

c. Pola pengasuhan yang mengabaikan

Pola pengasuhan ini orang tua tidak terlibat dalam kehidupan anak. Anak yang diasuh dengan pengasuhan yang mengabaikan cenderung tidak memiliki kompetensi sosial seperti pengendalian diri yang buruk.

d. Pola pengasuhan permisif

Orang tua dalam pola pengasuhan ini sangat terlibat dalam kehidupan anak namun membebaskan keinginan anak. Anak kurang belajar menghormati orang lain dan kesuliltan dalam mengendalikan diri. Anak yang dihasilkan dari pengasuhan ini cenderung mendominasi, egosentris, tidak taat aturan, dan kesulitan dalam pergaulan dengan teman sebaya. Dampak pola asuh akan memberikan pengaruh atas sifat-sifat anak, seperti:

1) Suka memberontak

2) Prestasinya rendah

3) Suka mendominasi 
4) Kurang memiliki rasa kepercayaan diri

5) Kurang bisa mengendalikan diri, dan

6) Tidak jelas arah hidupnya.

Ibu sebagai orang tua tunggal memiliki tingkat stress yang tinggi dibanding ibu yang mengasuh anaknya pada keluarga yang lengkap. Tingkat stress yang rasakan oleh ibu sebagai orang tua tunggal memiliki dampak langsung terhadap pola asuh ibu tunggal terhadap perilaku anaknya. Ibu yang mengalami tingkat stress yang tinggi kurang efektif dalam mengasuh anaknya, sehingga orang tua tunggal wajib menemukan cara mengatasi tingkat stress sehingga diharapkan dapat memberikan pola pengasuhan yang positif terhadap anaknya.

\section{Kecerdasan Sosial Anak Usia Dini}

\section{Kecerdasan Sosial}

Kecerdasan sosial merupakan kemampuan diri seseorang dalam pergaulan di masyarakat dan kemampuan interaksi sosial dengan lingkungan sekitarnya. Gagne mengungkapkan bahwa kecerdasan sosial adalah kemampuan seseorang dalam berhubungan dengan orang lain. Seseorang yang memiliki kemampuan kecerdasan sosial yang tinggi mampu menjalin komunikasi yang efektif dengan orang lain, mampu berempati dengan baik,mampu mengembangkan hubungan yang harmonis dengan orang lain, serta mempunyao kemampuan memahami suasana hati, motif dan niat orang lain. Gardner berhasil mengeksplorasi dimensi lain dari kecerdasan manusia yang berada di otak kiri dan kanan. Gardner berhasil mengidentifikasi 9 macam kecerdasan manusia, yakni

1). Verbal-linguistic intelligence,

2). Logical-mathematical intelligence,

3). Spatial-visual intelligence,

4). Bodily-kinesthetic intelligence,

5). Musical intelligences,

6).Interpersonal intelligence,

7). Intrapersonal intelligence,

8). Naturalist intelligence, 
9). Existential intelligence. ${ }^{23}$

Kecerdasan sosial (Interpersonal intelligence) menurut Gardner kecerdasan sosial merupakan seseorang yang mempunyai kemampuan sebagai berikut ${ }^{24}$ :

1). Kemampuan untuk menyelesaikan masalah yang terjadi dalam kehidupan sehari-hari

2). Kemampuan untuk menghasilkan persoalan-persoalan baru dan mampu menyelesaikan permasalahan tersebut dengan efektif dan efesien.

3). Kemampuan untuk menciptakan sesuatu yang akan menimbulkan penghargaan dalam kehidupan seseorang.

Selain itu, ciri khas yang menunjukkan kecerdasan sosial pada anak usia dini, yaitu:

1). Senang bermain dengan teman sebaya, namun juga perlu waktu untuk bermain sendiri.

2). Sifat individu masih sangat kuat

3). Sering timbul pertengkaran saat bermain

4). Sangat membutuhkan perhatian dari orang dewasa.

5). Sedang belajar membuat pilihan-pilihan yang benar. ${ }^{25}$

Kecerdasan sosial juga dapat diartikan sebagai segala sesuatu yang berlangsung antar dua pribadi, mencirikan proses-proses yang timbul sebagai suatu hasil dari interaksi individu dengan individu lainnya. Kecerdasan sosial menunjukkan kemampuan seseorang untuk peka terhadap perasaan orang lain. Mereka cenderung untuk memahami dan berinteraksi dengan orang lain sehingga mudah bersosialisasi dengan lingkungan di sekelilingnya.

Kecerdasan sosial mempunyai tiga dimensi utama, yaitu social sensitivity, social insight, dan social communication ${ }^{26}$

${ }^{23}$ http://www.niu.edu/facdev/resources/guide/learning/howard_gardner_theory multiple int elligees.pdf, diunduh pada tanggal 14 Maret 2014. Lihat Gardner, Howard. 2003. Multiple Intellegencies Kecerdasan Majemuk Teori dalam. Praktik. Terjemahan Alexander Sindoro. Judul Asli : Multiple Intelligences. Jakarta: Interaksara.

${ }^{24} \mathrm{H}$. Gardner, Frames of Mind: The Theory of Multiple Intellegences,Terjemahan,(Jakarta: Gramedia, 2000), 39.

${ }^{25}$ Trianto. 2010. Mengembangkan Model Pembelajaran Tematik. (Jakarta: PT Prestasi pustakaraya ), 18 . 
95 | MUSAWA, Vol. 13 No.1 Juni 2021 : 82-105

Tabel Dimensi Kecerdasan Sosial

\begin{tabular}{|c|c|c|}
\hline $\begin{array}{l}\text { Social Sensitivity } \\
\text { (Kepekaan Sosial) }\end{array}$ & $\begin{array}{c}\text { Social Insight } \\
\text { (Wawasan Sosial) }\end{array}$ & $\begin{array}{c}\text { Social Communication } \\
\text { (Komunikasi Sosial) }\end{array}$ \\
\hline $\begin{array}{l}\text { - } \text { Sikap Empati } \\
\text { - } \quad \text { Sikap Prososial }\end{array}$ & $\begin{array}{ll}\text { - } & \text { Kesadaran diri } \\
\text { - } & \text { Pemahaman situasi } \\
& \text { sosial dan etika sosial. } \\
\text { - } & \text { Keterampilan } \\
& \text { Pemecahan Masalah }\end{array}$ & $\begin{array}{l}\text { - Komunikasi Efektif } \\
\text { - Mendengarkan } \\
\text { Efektif }\end{array}$ \\
\hline
\end{tabular}

\section{a. Social Sensitivity}

Kemampuan untuk mampu merasakan dan mengamati reaksi-reaksi atau perubahan orang lain yang ditunjukkannya baik secara verbal maupun non verbal. Anak yang memiliki sensivitas yang tinggi akan mudah memahami dan menyadari adanya reaksi-reaksi tertentu dari orang lain, entah reaksi tersebut positif ataupun negatif. Adapun indikator dari sensivitas sosial itu sendiri menurut Safaria adalah sebagai berikut;

1. Sikap Empati

Empati adalah pemahaman kita tentang orang lain berdasarkan sudut pandang, perspektif, kebutuhan-kebutuhan, pengalamanpengalaman orang tersebut. Oleh sebab itu sikap empati sangat dibutuhkan di dalam proses bersosialisasi agar tercipta untuk suatu hubungan yang saling menguntungkan dan bermakna.

${ }^{26}$ Safaria, Interpersonal Intelegence: Metode pengembangan Kecerdasan Interpersonal anak, (Yokyakarta: Amara Books, 2005), 23. 


\section{Sikap Prososial}

Prososial adalah tindakan moral yang harus dilakukan secara cultural seperti berbagi, membantu seseorang yang membutuhkan, bekerjasama dengan orang lain dan mengungkapkan simpati.

\section{b. Social Insight}

Kemampuan seseorang untuk memahami dan mencari pemecahan masalah yang efektif dalam satu interaksi sosial, sehingga masalah-masalah tersebut tidak menghambat apalagi menghancurkan relasi sosial yang telah di bangun.Di dalamnya juga terdapat kemampuan dalam memahami situasi sosial dan etika sosial sehingga anak mampu menyesuaikan dirinya dengan situasi tersebut.Fondasi dasar dari social insight ini adalah berkembangnya kesadaran diri anak secara baik. Kesadaran diri yang berkembang ini akan membuat anak mampu memahami keadaan dirinya baik keadaan internal maupun eksternal seperti menyadari emosi-emosinya yang sedang muncul, atau menyadari penampilan cara berpakaiannya sendiri, cara berbicaranya dan intonasi suaranya. Adapun indikator dari social insight, di antaranya:

1) Kesadaran Diri

2) Pemahaman situasi sosial dan etika sosial

3) Keterampilan Pemecahan Masalah

\section{c. Social Communication}

Penguasaan keterampilan komunikasi sosial merupakan kemampuan individu untuk menggunakan proses komunikasi dalam menjalin dan membangun hubungan interpersonal yang sehat. Dalam proses menciptakan, membangun dan mempertahankan relasi sosial, maka seseorang membutuhkan sarananya. Tentu saja sarana yang digunakan adalah melalui proses komunikasi, yang mencakup baik komunikasi verbal, non verbal maupun komunikasi melalui penampilan fisik. Keterampilan komunikasi yang harus dikuasai adalah keterampilan mendengarkan afektif, keterampilan berbicara efektif, keterampilan public speaking dan keterampilan menulis secara efektif ${ }^{27}$.

\footnotetext{
${ }^{27}$ Anderson S J, Glantz SA, Ling PM. Emotions for sale: cigarette adversiting and women's phychososial needs, Research Paper, 2004.
} 
Individu yang memiliki kecerdasan sosial yang tinggi, tentunya memiliki karakteristik-karakteristik yang berbeda dengan individu yang tidak memiliki kecerdasan sosial. Dalam buku Sosial Intelligence, Safaria menyebutkan karakteristik anak yang memiliki kecerdasan sosial yang tinggi, yaitu:

1) Mampu mengembangkan dan menciptakan relasi sosial baru secara efektif;

2) Mampu berempati dengan orang lain atau emmahami orang lain secara total;

3) Mampu mempertahankan relasi sosialnya secara efektif sehingga tidak musnah dimakan waktu dan senantiasa berkembang semakin intim/mendalam/penuh makna;

4) Mampu menyadari komunikasi verbal maupun non verbal yang dimunculkan orang lain, atau dengan kata lain sensitive terhadap perubahan sosial dan tuntutan-tuntutannya;

5) Mampu memecahkan masalah yang terjadi dalam relasi sosialnya dengan pendekatan win-win solution serta yang paling penting adalah mencegah munculnya masalah dalam relasi sosialnya;

6) Memiliki keterampilan komunikasi yang mencakup keterampilan mendengarkan efektif, berbicara efektif dan menulis secara efektif. Termasuk di dalamnya mampu menampilkan penampilan fisik yang sesuai dengan tuntutan lingkungan sosialnya.

Kecerdasan sosial tidak semata-mata dimiliki oleh setiap orang tetapi untuk memilikinya ada proses yaitu proses pembelajaran sosial. Pembelajaran sosial pada zaman ini masih terus dikembangkan terutama dalam dunia pendidikan yang masih terus diterapkan di banyak sekolah.

\section{Kecerdasan Sosial Anak Usia Dini}

Peranan ibu dalam mendukung kecerdasan sosial anak dapat dilakukan dengan mengajaknya bergaul dan bertemu dengan orang lain serta mendorong anak berkomunikasi dan berinteraksi dengan lingkungannya. Hal yang perlu dilakukan ibu dalam mengembangkan kecerdasan sosial anak sebagai berikut: 
a. Ajari Anak tentang Emosi.

Ibu memperkenalkan kepada anak untuk belajar mengenal berbagai macam bentuk emosi, seperti; bahagia, sedih, marah, kecewa, gugup, takut dan frustasi yang betujuan supaya anak mampu memahami dan mengungkapkan emosi yang mereka rasakan.

b. Dukung anak untuk lebih banyak berinteraksi dengan orang lain.

Ibu memberikan ruang yang besar kepada anak untuk sering melakukan kegiatan yang melibatkan orang banyak, sehingga mampu bersosialisasi, bergaul dengan teman-temannya, saudara, tetangga maupun orang lain.

c. Selalu mulai dengan pertanyaan.

Langkah untuk mengembangkan kemampuan ini, dengan memberikan pertanyaan sebagai bentuk respon dirinya. Tujuannya melatih anak untuk mengambil atau membuat keputusan.

d. Tunjukkan kepedulian kepadanya.

Anak yang memperoleh kepedulian dari orang tuanya cenderung memiliki keprinadian yang mudah simpatik, orang tua perlu mengajarkan anak merespon terhadap perhatian dan kepedualian emosi yang diberikan.

e. Ajarkan cara memperhatikan perasaan orang lain.

f. Jangan asala memuji

Memberikan pujian pada anak saat melakukan kebaikan adalah hal yang perlu dilakukan ole h oran tua, namun sebaiknya jangan asal memuji.

\section{PEMBAHASAN}

Pola asuh ibu sebagai orang tua tunggal dalam mengembangkan keterampilan sosial anaknya yang masih berusia dini di lihat dari 3 aspek yaitu; Aspek Social Sensitivity, Aspek Social Insight, Aspek Social Communication. Pada penelitian ini menunjukkan pola asuh yang dilakukan ibu sebagai orang tua tunggal dalam 3 aspek kecerdasan sosial pada anak serta menjelaskan bentuk kecerdasan anak usia dini dari pola asuh yang di terapkan oleh ibu sebagai orang tua tunggal. 
99 | MUSA WA, Vol. 13 No.1 Juni 2021 : 82-105

\section{Aspek Social Sensitivity}

Pada Aspek Social Sensitivity ini ada dua indikator yang menjadi bahan pengukuran apakah anak menunjukkan kecerdasan sosial pada aspek ini yaitu; Sikap empati dan sikap prososial yang di tunjukkan anak dalam bersosialisasi dengan orang lain.

Dari hasil wawancara dengan orang tua tunggal (ibu) menunjukkan bahwa ibu selalu memberikan perhatian dan pendidikan kepada anaknya, peran ibu sebagai orang tua tunggal dirasakan sangat berat dalam mengembangkan kecerdasan anak, waktu berinteraksi dengan anaknya tersita dengan beban ibu sebagai kepala keluarga untuk mencukupi kebutuhan hidup keluarganya.

Dalam membina kemampuan pada aspek ini ibu mengajarkan anak untuk saling membantu dan memberikan bantuan kepada orang lain, ibu memberikan pembiasaan dan memotivasi anak untuk memahami orang lain, memberikan bantuan dan saling memberi.

Sikap Empati, sikap empati yang di tunjukkan dari anak dengan pola asuh ibunya yang di gambarkan diatas menunjukkan sikap empati anak ke pada orang tua dan orang-orang disekitanrnya. Bentuk empati yang ditunjukkan anak yaitu anak mendengarkan apa yang disampaikan oleh ibunya dan orang lain yang berinteraksi padanya, memberikan respon positif dari keadaan atau situasi yang dihadapi orang tua ataupun orang lain disekitarnya, tindakan itu dapat dilihat dari respon anak ketika ibunya pulang kerja, anak selalu menanyuakan kepada ibunya apakah ibunya capek kerja dan lain-lain.

Respon yang ditunjukkan anak diatas merupakan salah satu bentuk sikap empati anak, sikap empati anak dapat dikembangkan karena bimbingan dan pembiasaan yang dilakukan oleh orang tua. Menurut Syifa ${ }^{28}$ sikap empati anak dapat meningkat dengan memberikan pembiasaan-pembiasaan yang positif dalam proses pembelajarannya.

Aspek sikap Prososial, sikap prososial anak ditunjukkan dengan perilaku anak yang mencermikan sikap suka membantu, suka menolong orang lain. Sikap

\footnotetext{
${ }^{28}$ Aulia Nurfazrina Syafira, Yusuf M H, Sumardi. Analisis Kemampuan Empati Anak Usia 5-6 Tahun. (Jurnal PAUD Agapedia, Vol. 4, No. 2, 2020), 285-299.
} 
prososial yang di tunjukkan anak dari pola asuh ibu sebagai orang tua tunggal yakni anak menunjukkan sikap menghargai temannya, mau menerima pendapat temannya, serta memberikan penghargaan kepada temannya.

Dalam membentuk sikap prososial anak usia dini, ibu sebagai orang tua tunggal dalam penelitian ini memberikan pembelajaran dengan membiasakan anak pada kegiatan-kegaiatan sosial. Hal tersebut sejalan dengan yang hasil penelitian Olivia yang mengatakan metode pembiasaan yang di terapkan apada anak usia dini berpengaruh signifikan terhadap perkembangan kecerdasan sosial anak. $^{29}$

\section{Aspek Social Insight.}

Pada Aspek Social Insight ini ada tiga indikator yang menjadi bahan pengukuran apakah anak menunjukkan kecerdasan sosial pada aspek ini yaitu; Kesadaran diri, Etika Sosial dan Memecahkan Masalah yang di tunjukkan anak dalam bersosialisasi dengan orang lain.

Kesadaran diri, pada indikator ini peneliti menemukan bahwa sifat individual yang ditunjukkan masing-masing anak masih sangat tinggi, ada beberapa faktor yang menyebabkan hal tersebut menurut ibunya yang mengasuh yakni disebabkan karena anak yang diasuh oleh orang tua tunggal mempunyai kebiasaan ingin menguasai sesuatu, karena anak belum mampu menyesuaikan diri terhadap lingkungan sekitarnya, dan interaksi antara anak dan orang tuanya kurang banyak sehingga anak tidak tau mengatur perubahan emosi dalam dirinya. Menurut Carver \& Humpries mengemukakan bahwa anak yang memiliki kesadaran diri yang tinggi mampu mengontrol dan mempunyai sifat sensitivitas yang tinggi dalam menghadapi penolakan lingkungan sosial disekitarnya ${ }^{30}$.

Pemahaman Situasi Sosial dan Etika Sosial, Ibu melakukan pembinaan pada anak dengan cara mengajarkan anak untuk tertib mulai dari bangun tidur hingga melakukan aktivitas sehari-hari seperti makan, menonton, bermain,

\footnotetext{
${ }^{29}$ Olivia Greta Maldarisa, dkk. Hubungan antara Metodepembiasaan dengan Prilaku Reliqius pada Anak Usia Dini di PAUD Kelompok Bermain Mawar 02 Kabupaten Lumajang. (Jurnal Pendidilan Luar Sekolah, Vol. 1, No. 1, 2017), 1-9.

${ }^{30}$ Nurul Afrianti, Profil Kecerdasan Sosial Siswa SMA di Kota Bandung Sebagai Studi Awal Penyelenggaraan Layanan Bimbingan Konseling, (Jurnal Ilmiah Psikologi Terapan, Vol.5, No. 1, 2015), 40-59.
} 
bertamu di rumah teman, meminta tolong dan lain-lain. Anak dibiasakan untuk mematuhi atura-aturan terhadap sebuah situasi. Inilah yang dinamakan sebagai etiket yaitu kadah sosial yang mengatur perilaku mana yang harus dilakukan dan perilaku mana yang dilarang untuk dilakukan, tujuannya agar anak dapat menyesuaikan perilakunya terhadap situasi sosial ${ }^{31}$.

Keterampilan Pemecahan Masalah, Ibu sebagai orang tua tunggal selalu mengingatkan aturan-aturan tersebut kepada anaknya, dengan begitu anak akan terbiasa dengan etika-etika dalam bersosial. Dalam melaksanakan etika bersosial tidak jarang anak akan mendapatkan masalah, dalam membantu anak menyelesaikan masalah ibu dapat menerapakan cara yang membantu anak memecahkan masalahnya dengan cara mengajak anak berbicara, membiarkan anak menceritakan semua masalah yang dia dapatkan selama aktivitasnya bersosialisasi, ibu hanya sebagai pengarah untuk membantu anak untuk memecahkan masalahnya sendiri. Strategi yang tepat digunakan ibu dalam membantu anak memecahkan masalah dengan menggunakan strategi kolaborasi yang mana melibatkan kerjasa masa antara kedua belah pihak. menggunakan strategi kolaborasi yaitu dengan cara bernegosiasi dengan anak, melakukan mediasi, dan fasilitasi. ${ }^{32}$

\section{Aspek Social Communication.}

Komunikasi sosial merupakan kemampuan individu untuk menggunakan proses komunikasi dalam menjalin dan membangun hubungan kecerdasan sosial yang sehat. Dalam proses menciptakan, membangun, dan mempertahankan relasi sosial, maka seorang anak usia dini membutuhkan sarananya. sarana yang digunakan adalah melalui proses komunikasi, baik berupa komunikasi verbal, non-verbal maupun komunikasi melalui penampilan fisik. Pada Aspek Social Communication ini ada dua indikator yang menjadi bahan pengukuran apakah anak menunjukkan kecerdasan sosial pada aspek ini yaitu; Komunikasi Efektif dan Mendengarkan Efektif yang di tunjukkan anak dalam bersosialisasi dengan orang lain.

\footnotetext{
${ }^{31}$ Safaria, Interpersonal Intelegence: Metode pengembangan Kecerdasan Interpersonal anak, (Yogyakarta: Amara Books, 2005), 66.

${ }^{32}$ Ibid, 25.
} 
Komunikasi Efektif, pola komunikasi yang efektif dapat diterapkan oleh orang tua dan guru pada anak usia dini merupakan pola komunikasi yang demokrasi dan interaktif, karena penerapan pola komunikasi yang benar sebagai bentuk interaksi antara orang tua dengan anak maupun antaranggota keluarga serta lingkungan sosial anak memiliki implikasi terhadap nilai-nilai perkembangan emosi anak. nilai yang dimaksud merupakan nilai yang berhubungan dengan kualitas-kualitas emosi anak, antara lain nilai-nilai tentang sikap hormat, tata kerama atau sopan-santun, kesabaran dalam menyelesaikan masalah masalah, serta toleransi yang menjadi dasar terbentuknya sikap empati anak. Dengan demikian, anak-anak akan tumbuh dan berkembang menjadi pribadi yang cerdas, baik secara intelektual maupun emosional, yang akhirnya menjadi dasar bagi kecerdasan yang lain, yaitu kecerdasan sosial, moral, dan spiritual. Dalam proses komunikasi tersebut, anak akan belajar mengenal dirinya maupun orang lain, serta memahami perasaannya sendiri maupun orang lain. ${ }^{33}$

peran ibu sebagai orang tua tunggal dalam mengajarkan anak usia dini dalam berkomunikasi dan bersosialisasidengan cara mengajak anak berkomunikasi untuk mengungkapkan perasannya dengan menyebut nama perasaan itu misalnya mengenalkan perasaan senang, anak akan ditunjukkan bagaimana gambar ekspresi senang, menunjukkan contoh ekspresi senang misalnya dengan tersenyum atau tertawa. Menurut Johnson ada tiga cara mengungkapkan yaitu mengidentifikasikan atau menyebut nama perasaan itu, menggunakan kiasan perasaan, menunjukkan bentuk tindakan yang ingin dilakukan. $^{34}$

Mendengarkan Efektif, pola yang diterapkan ibu sebagai orang tua tunggal pada indikator ini yakni meransang kemampuan anak untuk mampu mendengar dan menanggapi respon yang efektif. Selain meransang kemampuan mendengar anak juga ibu membiasakan untuk mau mendengarkan pendapat anak, mendengarkan pendapat anak sama pentingnya dengan meransang kemampuan

\footnotetext{
${ }^{33}$ Yuli Setyowati, Pola Komunikasi Keluarga dan Perkembangan Emosi Anak, (Jurnal Ilmu Komunikasi, Vol. 2, No. 1, 2005), 67-78.

${ }^{34}$ Safaria, 2005. Interpersonal Intelegence: Metode pengembangan Kecerdasan Interpersonal anak, (Yogyakarta: Amara Books), 142.
} 
mendengar anak dalam memenuhi kebutuhan emosional anak. Dampak sosial pada anak jika orang tua mengabaikan pendapat anak seperti kurang percaya diri, anak tidak patuh pada orang tua.

Pola didik ibu yang selalu mendengarkan pendapat anak akan menumbuhkan rasa percaya diri pada anak, hubungan emosional anak dan orang tua akan terjalin lebih baik lagi. Buatlah kontak mata dengan anak saat mendengar pendapat yang diutarakannya, merespon pembicaraan anak setelah selesai berbicara bukan memotong pembicaraan anak selagi masih berbicara serta sesekali mengikuti ide atau pendapat anak. Jika ide atau pendapat yang disampaikan anak kurang tepat, sebaiknya orang tua mengingatkan dan menjelaskan dengan bahasa yang mudah dipahami anak serta dengan intonasi yang lemah lembut mengapa ide atau pendapat anak itu salah atau tidak diterima oleh orang tuanya.

\section{KESIMPULAN}

Kecerdasan sosial terdiri dari aspek social sensitivity, social insight, dan social communication. Aspek kecerdasan sosial ini yang harus dimiliki anak usia dini. Kecerdasan sosial mencakup sikap empati, prososial, kesadaran diri, pemahaman situasi sosial dan etika sosial, keterampilan pemecahan masalah, komunikasi efektif, mendengarkan efektif serta mampu memimpin kelompok. Keterampilan ini dapat diajarkan kepada anak-anak dimulai sejak dini oleh orang tuanya, ibu yang berperan sebagai orang tua tunggal mempunyai cara tersendiri untuk membantu perkembangan anak-anaknya karena kecerdasan sosial pada anak usia dini tidak dimiliki oleh anak secara alami, tetapi harus ditumbuhkan dan dikembangkan oleh orang tua dengan mengembangkan aspek sosial dan emosi anak usia dini. Itulah sebabnya diperlukan berbagai metode yang dapat digunakan untuk mengembangkannya. Salah satu metode yang dapat digunakan orang tua dalam mengembangkan aspek sosial dan emosi pada anak usia dini, yaitu melalui keteladanan. Pola Asuh yang diterapkan ibu sebagai orang tua tunggal menerapkan pola asuh demokratis dan pola asuh otoriter. Ibu yang menerapkan pola suh demokrasi pada anak menunjukkan bersikap memenuhi aspek kecerdasan 
sosial seperti lebih tanggung jawab, besikap hangat, dan berprestasi. Sedangkan anak yang diasuh dengan pola asuh otoriter cenderung aspek yang ada pada kecerdasan sosialnya tidak berkembang dengan baik.

\section{DAFTAR PUSTAKA}

Afrianti, Nurul. Profil Kecerdasan Sosial Siswa SMA di Kota Bandung Sebagai Studi Awal Penyelenggaraan Layanan Bimbingan Konseling, Jurnal Ilmiah Psikologi Terapan, Vol.5, No. 1, 2015.

Agus Purwanto, dkk. Studi Eksploratif Dampak Pandemi COVID-19 Terhadap Proses Pembelajaran Online di Sekolah Dasar. Journal of Education, Phychology and Counseling, Vol. 2 No. 1. 2020.

Anderson S J, Glantz SA, Ling PM. Emotions for sale: cigarette adversiting and women's phychososial needs, Research Paper, 2004.

Ardiansyah, A., \& Arda, A. Peran Orang Tua dalam Proses Belajar Anak di Masa Pandemi Covid-19 dalam Menumbuhkan Sikap Ilmiah. Musawa, Journal For Gender Studies, Vol. 12, No. 1, 2020

Aulia Nurfazrina Syafira, Yusuf M H, Sumardi. Analisis Kemampuan Empati Anak Usia 5-6 Tahun. Jurnal PAUD Agapedia, Vol. 4, No. 2. 2020.

Brooks, J. The process of parenting. Yogyakarta: Pustaka Pelajar, 2011.

Gardner, H. Frames of Mind: The Theory of Multiple Intellegences,Terjemahan, Jakarta: Gramedia, 2000.

Goleman, Daniel. Working With Emotional Intelligence (terjemahan), Jakarta: PT. Gramedia Pustaka Utama, 2002.

Hening Hangesty Anuraga, Peran Orangtua dalam Meningkatkan Motivasi Belajar Peserta Didik Usia 6-12 Tahun, Fakultas Ilmu Pendidikan: Universitas Negeri Surabaya.

Heriyanto, H. 2018. Thematic Analysis sebagai Metode Menganalisa Data untuk Penelitian Kualitatif. Anuva. https://doi.org/10.14710/anuva.2.3.317-324

Hery Noer Aly. Ilmu Pendidikan Islam, Jakarta : PT. Logos Wacana Ilmu, 1999.

Hurlock, Elizabeth B. Perkembangan Anak. Jakarta: Erlangga, 2010

Imam Bernadib. Pengantar Ilmu Pendidikan Sistematis, Yogyakarta: Fakultas Ilmu Pendidikan, 1987 
105 | MUSA WA, Vol. 13 No.1 Juni 2021 : 82-105

Manshur, A. Pendidikan Anak Usia Dini. Bandung: Pustaka Pelajar, 2005.

Melia Dewi. Pola Pengasuhan Anak, Bandung: PT. Remaja Rosdakarya, 2012.

Moh. Rifai. Peranan Orang Tua sebagai Wali, Pembimbing, dan Pendidik pada Perkembangan Anak dalam Perspektif Pendidikan Agama Islam. Jurnal Pendidikan Dasar dan Pembelajaran Vol. 1 No. 1, 2011.

M. Save Dagun, Psikologi Keluarga, Jakarta: Rineka Cipta, 2011.

Olivia Greta Maldarisa,dkk. Hubungan antara Metodepembiasaan dengan Prilaku Reliqius pada Anak Usia Dini di PAUD Kelompok Bermain Mawar 02 Kabupaten Lumajang. Jurnal Pendidilan Luar Sekolah, Vol. 1, No. 1, 2017.

Pebriana, P., H. Analisis Penggunaan Gadget terhadap Kemampuan Interaksi Sosial Anak Usia Dini. Journal Obsesi Journal of Early Chilhood Education, Vol. 1, No. 1, 2017.

Peraturan Menteri Pendidikan Nasional No. 137 tahun 2014. Tentang standar Nasional Anak Usia Dini. Jakarta

Robbiyah, Dian E, Ramadhan W. Pengaruh Pola Asuh Ibu terhadap Kecerdasan Sosial Anak Usia Dini di TK Kenanga Kabupaten Bandung Barat. Jurnal Obsesi: Jurnal Pendidikan Anak Usia Dini, Vo. 2 No. 1, 2018.

Safaria, Interpersonal Intelegence: Metode pengembangan Kecerdasan Interpersonal anak, Yokyakarta: Amara Books, 2005.

Santrock, John W. Child Development. New York: McGraw-Hill, 2010.

Sardiman. Interaksi dan Motivasi Belajar Mengajar, Jakarta: Raja Grafindo Persada, 1996.

Stahl, R.J., Cooperative Learning in Social Studies, Handbook for Teachers, USA, Kane Publishing Service, Inc, 1994.

Syafi'ah. Peran Orang Tua dan Keluarga, Jurnal Sosial Budaya Vol.9 No.1, 2012.

Trianto. Mengembangkan Model Pembelajaran Tematik. Jakarta: PT Prestasi pustakaraya , 2010.

Yuli Setyowati. Pola Komunikasi Keluarga dan Perkembangan Emosi Anak, Jurnal Ilmu Komunikasi, Vol. 2, No. 1, 2005. 